\title{
REMARKS ON SOME CORRESPONDENCE BETWEEN ANKARA AND YEMEN CONCERNING THE LAST OTTOMANS AT YEMEN IN THE EARLY 1920s
}

\author{
M. Lutfullah Karaman \\ Fatih University, Istanbul-Turkey
}

\begin{abstract}
As is historically known well, the part and parcel of Yemen, albeit so remote, has come and been under Ottoman control and/or influence for some 400 years. It was such a continual presence that, though intermittently, persisted from somewhere in the $16^{\text {th }}$ century till the early decades of the $20^{\text {th }}$ century. It was such a presence, again, during which many Ottoman citizens resided in Yemen and served as incumbents, of civilian or military background. It needs, accordingly, to be emphasized that although formally administrative relations may have ceased with the obvious defeat and de facto end of the Ottoman political power, after the termination of the First World War, the relations would be far from over in yet another aspect, that is, for the human element: those numerous civilians and military officials of Ottoman-Turkish stock who had remained behind, fortunately still surviving. Accordingly, its focus being on that specified human aspect, this paper will attempt to reopen a scarcely explored leaf in history, within the multi-faceted outline of Yemeni history under the Ottoman governance, with the special aid of a series of documents found (as untouched and thus unknown for the public till the attempt of making them open by this paper) in the Republican Archives of the Turkish Prime Ministry, pertaining to the fate of the remnants of Ottomans
\end{abstract}


stranded there in the aftermath of the First World War and during the subsequent period of the National Struggle, a time when while the Ottoman Empire vanishes and ultimately relinquishes control of Yemen, a totally new, different Turkey appears on the same stage of the worldsubject matter.

Key Words: the (last) Ottomans at Yemen, Imām Yahyā, Maḥmūd Nadīm, Governor(ate) of Yemen, Turkish National Assembly

Historically it is the fact that, as far as the case of Yemen within the context of Ottoman-Turkish governance and their reciprocal relations are concerned, a history can be adduced extending to the outset of the War of Independence. We concurrently know that the Northern Yemen (prior to its unification with the Southern one in 1990), cardinally identified with the Ottoman Yemen, had effectively come under Ottoman suzerainty and influence midway through the $16^{\text {th }}$ century, marking the incipience of a somewhat intermittent though overall continual presence that persisted till the dawn of the $20^{\text {th }}$ century, during which many Ottoman citizens, of civilian or military background, served and resided in. It needs, accordingly, to be emphasized that although formally administrative relations may have ceased with the encroachment of the War of Independence inasmuch as the Turkish government was concerned, the relations would be far from over in human perspective for a bulk of Yemenis, more notably for the numerous civilians and military officials of Ottoman-Turkish stock who had remained behind. Hence, within the multi-faceted outline of Yemeni history under the Ottoman governance, this paper will attempt to reopen a scarcely explored leaf in history, with the special aid of a series of documents extant in the Republican Archives of the Turkish Prime Ministry, pertaining to the fate of the remnants of Ottomans stranded there in the aftermath of the First World War during the aforementioned period when Ottomans effectively relinquished control of Yemen, as indeed a specific humane aspect of the unfolding of that particular history.

Before focusing on that specified aspect, it would be appropriate to recap the cornerstones of Yemeni history under Ottoman suzerainty, so as to place it well within its peculiar historical context and/or backdrop. In essence, the earliest sign of Ottoman interest in Yemen coincides with growing Portuguese colonial desire in the 
area, in the early decades of the $16^{\text {th }}$ century. The first steps of Ottoman reign within this milieu were taken during Yemen's spell under Mamluke rule, in line with the process culminating in the annexing of Egypt in Ottoman favor by Selim I (1517), with the subsequent move by Iskender, a local chieftain dominant in the greater part of Yemen, who declared his allegiance to the Sultan, by concomitantly commencing the Friday sermons by the Sultan's name. Afterwards, upon minor insurgences by some locals under political pretexts coupled by the escalating need to defy the mounting Portuguese challenge, an Ottoman fleet under the command of Khādim Suleymān Pasha enjoyed success in seizing the entire area known as Yemen, including Aden, in 1538 (Uzunçarş11, 1983: II, 391-397). To additionally note, a further campaign under Sinān Pasha's command during the era of Suleymān I, and a subsequent administrative settlement with local chieftains would mark defining moments during that first period of Ottoman control (Uzunçarş111, 1983: III/1, 26-30). However, insurgences led by locally powerful Zaydī imāms, also catalyzed by some administrative inadequacies of early Ottoman governors, were to follow shortly thereafter. Thus, from the 1630s, especially following Imām Qāsim's 40 year-revolt, Yemen has been abandoned to the charge of local imāms dominant throughout various parts of the region. It appeared to be a status undeterred until 1849, in which the Ottomans, during the reign of 'Abd al-'Majīd, reentered the region with forces led by Tawfīq Pasha, but more importantly until 1872, when Ghāzī Ahmad Pasha reinstated Ottoman control in the area coinciding with the sultanate of 'Abd al-'Azīz (Hourani, 1991: 228, 251).

Yemen, temporarily administered as a sanjaq of the eyālet of Abyssinia following the restoration of Ottoman control (Karal, 1983: VI, 128), gained, during the reign of 'Abd al-Hamid II, more formally "the status of a wilayet subject directly to the capital, comprising the sanjaqs of Șan' $\overline{\mathrm{a}}$ ', al-Hudayda, 'Asìr and Ta'izz," with the exception of Aden (Karal, 1983: VIII, 341; Mehmet Tevfik, 1993: 278-279), administered by the governors dispatched from the capital, under a singular system of taxation. Concurrently, the recognition of imāms as popular leaders subsisted. During the pertinent period in which Ottoman supremacy had been restored to endure a long time to come, the area encompassing Yemen had still not yet relinquished its vital position on the threshold of world trade routes. Inspired by the enormity of 
such revenue awaiting collection, the region witnessed an inexhaustible effort by European powers, first through missions, and afterwards through military expeditions, to gain footing on her soil. At this point, without denying the influence of inadequacies and errors perpetrated by Ottoman internal politics and governors, one must reiterate the indisputable influence of English activities seeking fulfillment of colonial desires, conducive toward deteriorating the already weakened Ottoman hold on Yemen, on the incessant local upheavals idiosyncratic to Yemen under the Ottoman rule throughout the second half of the $19^{\text {th }}$ century, particularly escalating after the invasion of Aden in 1839, prompted by an unremitting encouragement of Yemeni imāms toward revolting against the central administration (for more detail on those internal revolts and particularly their external causes, see Sirma, 1994: 59-90).

Despite the taking of amendatory steps to cover particular flaws in administration especially during the reign of 'Abd al-Hamid II, in the face of the upheavals, the situation had nevertheless started, after a certain phase, to resemble a lost cause. In fact the unremitting insurgencies culminated in 1904 with the first major uprising of the $20^{\text {th }}$ century, initiated first by the declaration of $j i h \bar{a} d$ and the subsequent revolt of Imām Yahyā, who had previously assumed the title of imām following the death of his father and was to sustain it for 44 years until his tragic death upon the raid of his Șan( $\overline{\mathrm{a}}$ ' Palace (Ehiloğlu, 2001: 176). The import of the pertinent revolt lies in its settlement only through a truce in 1905, and the ensuing abandonment of Șan' $\overline{\mathrm{a}}$ ' and adjoining regions to the Imām's authoritative influence. Discontented with the loss of the region under such particular circumstances, however, the Ottomans were to soon deploy fresh troops, recapturing Șan' $\overline{\mathrm{a}}$ ' after a series of bloody battles, in spite of which, however, in the long run Imām Yahyā's regional dominance was to hold sway.

Concomittant with the ascendancy of the Union and Progress Party to control in the Empire's capital, the period beginning with 1910 produced a recuperated revolt once again of Yahyā on the one hand, and on the other a second uprising by a novel figure, Sayyid Idrīsì, another rebel who procured influence in the region of 'Asīr, under British auspices. Upon such developments, the Union and Progress government, prompted by their ascription to the rule under 
strong centralization, entrusted Ahmad 'Izzet Pasha with the task of quelling the revolts; soon embarking with the famous cruiser Hamidiye replete with a sizeable force on 18 February 1911, he then managed to first reopen the path to Șan'( $\overline{\mathrm{a}}$ ' with a swift operation in April, followed by the routing of Idrīsī in July. (It should be parenthetically noted that the troops arriving in Yemen included Mahmūd Nadim, who would later be officially the last governor of Yemen, as attested by the documents to be referred to hereof). Occasioned by the significant influence exercised by Imām Yahyā over Yemen and her population, what this time the Ottoman capital followed was the adoption of a more sensible policy, acquiring a permanent character with the agreement of Dacān on the $13^{\text {th }}$ of October, concluded by a series of negotiations between Maḥmūd Nadīm on behalf of Aḥmad 'Izzet and the Imām, the gist of which compelled the Imām to renounce all claims to emirate, in return for opulent privileges over the area he presided (Ehiloğlu, 2001: 134-135; for the text see Bayur, 1983: II/1, 45-47). To an enormous extent it was thanks to this treaty that, in the ensuing years, while struggle persisted between the central administration and Idrīsī, whose British allegiance set to become more intimate with the outbreak of the Great War, Imām Yahyā avoided partaking in an anti-Ottoman rebellion, contrarily lending aid, "both logistically and with the tribal forces under his command, to the Ottoman $7^{\text {th }}$ Army Corps stationed in Șan ( $\overline{\mathrm{a}}$, against the British base in Aden as well as for the strike against the troops of Idrīsī in 'Asīr" (Seyhun, 1997:3).

During the First World War Yemen was to become a subordinate military zone. As had been the case with other fronts in the Arabian Peninsula, the Ottomans would face the British, who managed to exert pressure on the coast with their hit-and-run strikes, aided by their navy, with the succinct objective of frustrating Turkish military force in the area and intimidating civilians residing in the shores of the peninsula. As the immediate outcome of the war relating to the region, neither could the Ottomans recapture Aden, nor would the British relinquish it (for greater detail regarding military developments see Gn.Kur., 1978: 413-626; for a greater emphasis on the humane aspect, refer to Seyhun, 1997: 10-37). Once news of armistice reached Yemen in 1918, a meeting by Governor Mahmūd Nadīm and Commander-in-Chief Aḥmad Tawfīq Pasha with the Imām followed 
suit. In principle, Yahyā was not opposing the surrender of the Corps to the British, except that he wished to withhold a portion of their weapons and ammunition for use against possible attacks targeting him afterward. Further details to one side, finally, the concluding days of December saw the delegates of the $7^{\text {th }}$ Corps and Yahyā convene with the British. Debates were to no avail, hence the internal status quo between the Ottoman corps and the forces of Idrīsi and the British prevailed; in the interim, a quantity of the weapons were conceded to the Imām, while the rest were sold to the tribes, the revenue of which was handed to the soldiers and marines unable to receive payment for months-on-end. Consequently, the $7^{\text {th }}$ Corps dismantled itself, simultaneously taking to task the reinforcement of the Imām's continuing resistance against the British penetrating inner Yemen (Ehiloğlu, 2001: 191-98).

Thus the end of the Great War, portending an overwhelming Ottoman defeat, equally meant the end of Ottoman rule over Yemen, and the abandonment of region to the governance of Yahyā marked the swansong of the Ottoman administration's Yemeni adventure, the culprit of the colossal bloodshed of innumerable unknown sons of the Empire. Inasmuch as the factual human aspect was concerned however, their fate was far from being sealed. What remained therein, in barren reality, were soldiers, as the remnants of the army despite its dissolution, unable in one way to return home, beside with a small number of officials and their families, now constituting the last Ottomans at Yemen. Accordingly, within the historical background delineated above, and in the light of the pertinent documents as divulged at the start, this paper will attempt to offer a critical analysis with respect to the fate of the just referred Ottoman sons and daughters ostensibly deserted to local administrators on the plains of Yemen, following the Ottoman-Turkish ceding of the pertinent territory, in the wake of the Great War and during the years epitomized by the struggle for national independence at home.

Upon observation of the mentioned documents, one will find that the bulk is comprised of various correspondences between Yemen and Ankara during the first half of the 1920s, the specific and overiding theme of which involves the hardship and helplessness encroaching upon the remaining Ottoman-Turks and their concomitant plea for support and care. An aspect within this context calls for specific 
emphasis: Although those remaining in Yemen were officials and their families still formally subject to the Ottoman administration of Istanbul, devoid of functionality owing to the then emergent Allied control, official applications and requests reflected via these documents, preponderantly signed under the seal of the Governorate of Yemen, were directed not to the by-then nominal government of Istanbul, but to the nascent assembly of Ankara (TBMM), steady on its way towards assuming de facto power. At this very point, if we bear in mind the staunch attitude to be espoused by Ankara in undertaking a conscious split with its Ottoman history subsequent to the War of Independence, not many clouds would hover for us so as to prefigure the twist such a saga was set to take for the last Ottomans at Yemen, with the help of the relevant historical documents, which indeed attest the abandonment of those remainders in Yemen to their destinies.

Beneath the arch of the matter elucidated above, the enormity of the plight besieging the Ottomans stranded in Yemen and, interrelatedly, of their nurtured expectations of adoption by the government of Ankara to whom they perhaps pragmatically resorted in hope, can be clearly exposed once the mentioned documents are taken into scrutiny, as it is a conspicuous issue frequently raised in the numerous letters alluded to. As a paragon example, among the many with similar context, it is of much worth to recall the very letter of request, dated 8 July 1922 and sent to the Turkish National Assembly government, carrying the signature, like many others, of Governor Mahmūd Nadīm, in articulation of the dire need to rally to the aid of the deserted in Yemen crippled by the exigencies of the circumstances (TC. BCA-030/10/260/750/22):

To the Honorable Presidency of the Committee of Executive Ministries of the Turkish National Assembly,

As raised and enunciated whenever circumstances permit and trustworthy channels present themselves, the destitution and privation of civil servants and administrators, officers, pensioners, widowers and orphans, under the guardianship of thou servant, has exceeded well beyond the tolerable limit, the previously unimaginable sufferings they have been coerced to undergo as a corollary of hunger and lack of clothing have surpassed the boundaries of endurance. Compelling 
these Turkish sons to flee with their family and subjects as an escape from destitution, of such sons who have sacrificed, as befits an Ottoman-Turk, all of what they had, including their families, in protection and defense of religion and the Motherland, who, forbearing unthinkable shortages and catastrophes, have performed their duties, day and night, seems absolutely irreconcilable with the glorious reputation and justice of our Exalted Government.

I assure your Excellency by bearing witness Allah the Almighty, that nurturing compassion and benevolence to the sons and daughters of this nation, ineffective in even eliciting a paucity of aid from our Lofty Empire's Capital despite numerous pleas by myself since the outbreak of the Great War, who remain powerless in procuring a meager daily bread, a yard of clothing for cover, a piece of sack for shelter, a drop of lamp oil for emancipation from darkness, is an imperative of the honor, glory and justice of our Government.

Although it remains evident that the denial of assistance by our Exalted Government, which otherwise is illustrious for mobilizing all means for the smallest issue bearing upon the interest of the Motherland, to these unfortunate souls has no doubt stemmed from known circumstances and lack of trustworthy channels, praise be to Allah, that providentially by virtue of the current marvelous policies exerted by our (Ottoman) government and our Grand National Assembly, at the expense of leaving the world in awe, and the boundless valiance and nobility of our National Forces, an accord has been reached, of late, with the governments, adjoining Yemen, of France and Italy, through which remittance to either the French Bank of Djibouti or the Bank of Rome in Masu, or the transfer of money thereto through a proxy under the liability of either of these countries has become possible; thus as previously submitted in the petition sent on 29 May 1338 (1922), I solemnly implore your Excellency, with utmost sincerity and supplication, for the immediate dispatch, for the time being, of a few thousand gold aqces specifically to be used to assuage the predicaments aforementioned. Under all conditions, the edict belongs truly to your highness.

Examining the contents of this document, juxtaposed with those bearing an immense resemblance, one may adduce the following points for further elucidation: a) that, even before this exemplary letter of request, there had already been a number of all but unan- 
swered pleas for help, directed to the governments of both Istanbul and Ankara; b) by the cultivation of the themes of religious and patriotic sacrifice and a vivid description of the distress, undoubtedly enormous by the attestation of the letter, the request is pervaded with a genre, imparting the perception of the Ottoman-Islam totality, which directly addresses the conscience of the government; c) a glowing though erroneous optimism in hope that the expected help would arrive now that there had been established peace with the major powers surrounding Yemen, ironically vindicating the twist of fate that had previously preempted their former requests of assistance (this is an evaluation specially corroborated upon investigation of later documents revealing no such help had been made).

At this point, as further and salient confirmation of the desertion of those in Yemen to their destinies, reflected by the just quoted document, it will be of great interest to make a short reference to another document in the form of an internal correspondence of the Ankara Government, dated 15 October 1922, by the Foreign Ministry addressing the Presidency of the Executive Committee, which essentially informs about another letter of request sent from Yemen (TC. BCA030/10/260/750/27). The pertinent content of the letter, apparently confining the former broader requests to simply asking an aid for at least those who had become disabled in the defense of Yemen to return home, as such unequivocally manifesting the extent of torment they had been inflicted with, may also be regarded as attesting their unfortunate state of being thrown into disrepute, more so when contrasted with later documents evidencing a lack of concrete response to their heartfelt calls.

As previously expounded, more documents can be adduced to justify a connection between Ankara's aloofness in offering tangible assistance to its nationals, with its deliberate disowning of its Ottoman past, unambiguous following the War of Independence, during which it had not been evident. A noteworthy example is a letter of request sent by an official from Yemen to the Foreign Ministry, dated 9 December 1922, expressing grievances regarding a lack of confirmation, affirmative or negative, whether they had received the official documents of the Governorate of Yemen supposedly dispatched six months ago (TC. BCA-030/10/260/750/28). In support of the same fact within a distinct context, perhaps the subsequent point is worth 
reminding: As far as can be traced from the documents, falling again on deaf ears was a similar request made by the Governor of Yemen, on 9 September 1922, to the Turkish National Assembly, of mobilizing military help for Imām Yahyā, on grounds of his active opposition, in solemn Ottoman allegiance, against the British supported Idrīsī since the incipience of the armistice, highlighting the massive imbalance of power in the favor of Idrīsī (TC. BCA030/10/260/750/26).

Keeping in mind the earlier accentuated political inclination, embraced prospectively by the new Turkish ruling elites, of eschewing or at best leaving aside its Ottoman-Islamic heritage, it is perhaps appropriate, by virtue of taking recourse to a series of documents, to further elucidate the nature in which we have reached our previously propounded argument, namely the virtual abandonment of the remaining Ottomans in Yemen to their destinies. A folder of documents at hand, beacon like inasmuch as this case is concerned, comprises a series of correspondences preponderantly between the National Defense Ministry and Presidency of the Turkish National Assembly during the opening phases of 1923 (TC. BCA-30/10/260/750/31). Imbued directly with the overriding incentive of those who had remained in Yemen following the Great War and armistice and with applicable decisions in relation, additionally revealing the data relating to their classified population as well as to the fulfillment of their demands, the pertinent correspondences conclude with the edict decreed by the Committee of Executive Ministries that no such funding for their cause can be allocated, predicated upon a pretext that they are no longer attached to the Turkish Army. It appears to be also a decision ultimately precipitated upon the presentation of an ostensible list of those who had remained either voluntarily or with the request of the Imam. Even though a minor part of the list comprised by the documents is composed of voluntary residents; when taking the dates of those correspondences into particular consideration, coinciding with the milieu wherein the Sultanate had only just been abolished, they can ultimately be read and certainly be evaluated as a crystallization of the central policy of the nascent Turkish regime, that is, precisely a lust to shrug off its Ottoman political past, even in its human dimension. The following directly related pieces are worth mentioning: 
To the Honorable Presidency of the Committee of Executive Ministries,

Presented to your excellence is the letter sent by the Istanbul Commandership, dating 17 January 1923 with the number 1746/1847, and its attachment, in unison, as regards whether or not appropriations are to be disbursed, in accordance with the applicable ruling, to those who departed from Yemen following the armistice, and those who remained in Yemen on whose behalf their relatives in Istanbul have applied for ...

Representative of National Defense (signature)

To the Honorable Presidency of the Committee of Executive Ministries,

This is the response to the decision, dating 19.2.39, made by your exalted office of presidency. Hereby attached is the list of officers and officials who have remained in Yemen voluntarily or with the order of the honorable Imām. Sir, I implore you for an immediate decision and pertinent permission for our subsequent notification with regard to the procedure pertaining to their appropriations.

Representative of National Defense (signature)

To the Ministry of National Defense

Ankara/31.3.39 (1923)

In consequence of the Committee of Executive Ministries' due appraisal, during their meeting, of your respectable petition dating 25.3.39, with the Office of Accounts number 5236, which appeals for a decisive clarification of the ambiguity besetting the requested allocations for those officers and officials remaining in Yemen and Șan ‘ $\bar{a}$ ' voluntarily or with the order of the honorable Imām, it has been decided that no such appropriations will be given, on grounds of the cessation of their relations with the Turkish Army.

Chairman of the Committee of Executive Ministries (signature)

In corroboration of our evaluation made above within the exact context, there exists another letter (to be found again in the same 
folder of documents, referred to just above), sent to the Governorate of Yemen under the signature of the Presidency of the Ankara Government, which is too striking to ignore, insofar as it constitutes the final answer to the recurring campaign for assistance to those remaining in Yemen, made under the signature of the Governor of Yemen, in compensative assuagement of the entailed torment acquired through what they resolutely believed had been a struggle and sacrifice in defense of a greater interest. While from one vantage point the letter praises the loyalties and altruism of its Yemeni correspondents, locals and Turkish officials alike, from another, it expresses their inability to respond to the expected financial assistance, citing internal adversities and privations encountered by the government itself, thus culminating with an advice/request to make do with their own resources. Although the cited pretext may suffice for their acquittal up to a certain extent, embarking from the general impression reflected by several other documents, related and partially referred to in this paper, there exists overwhelming reason to believe that the pertinent response of Ankara is a manifest extension of its political direction of severing all bonds subsequent to the War of Independence, which therefore can once again be regarded as a concluding manifestation of the expressed theme of this paper, namely the abandonment of the last Ottomans in Yemen to their precarious destinies by the new, Republican Turks that had gained administrative supremacy in Turkey:

Turkish National Assembly Presidency of the Executive Committee of Ministries

To Mahmūd Nadīm Beg, the Governor of Yemen,

The stern determination and valiance exerted by the altruistic folk of Yemen as well as officials, officers, and soldiers stayed there, in defiance of the most horrendous kinds of deprivation and lack of communication with the Capital, and their reinforcement of ties with the Motherland at every given opportunity, deserves the gratification and indebtedness of our National Government. Your excellence, you may rest assured that our National Government will incessantly cherish, in particular, your resolution to remain in your post, for which you were compelled to offer physical and mental sacrifices of excessive caliber, despite constant pressure and threats made by Grand Vizier Damad 
Farīd and cohorts. Lamentably, however, encumbered by current financial exigencies, our Government is currently unable to execute your demands of assistance, sincerely desired by all, hence, Sir we beseech you to manage, to the best of your power, with local revenues.

Chairman of the Executive Committee of Delegates

By way of conclusion, when evaluated from within the context of Ottoman-Yemen relations extending, including interims, to 400 years, the human element, which, as divulged by the vernacular of the documents referred to in this paper, all the way appears to have been extravagantly manipulated, or stated more pungently, dissipated, became in the end incorporated into the ranks of the first to be "forgotten," rather than the first to be "saved," once separation befell; thus consequently, from the human perspective, the incumbent politics of Turkey for centuries turned Yemen in the eyes of the ordinary Turks to be almost invariably recalled as a "grave to the Turk," such a conception transforming in time to a "forgotten place," in concordance with the increasingly introvertive policy of alienation by the Republican governments from its Ottoman past at large. On a more poignant note, while for a long time, as the saying goes, coffee had come from Yemen to appease its Ottoman addicts, then, occasioned by an opulence of blood spilled in the name of maintaining centralized control over the region from the beginning of the era of Constitutional Monarchy, the taste of the coffee has come to render forever bitter, reflecting perhaps the exact incentive behind the remembrance of Ottoman Yemen as an agony-inspiring land, as alluded to so sensitively in a chant murmured for generations repetitiously by parents who had their sons perish in the frontiers:

No cloud hovers in the sky, what smoke is this?

No death roams in the quarters, whose wail is this?

That land of Yemen, how cruel 'tis,

Alas ... it is that Yemen, whose rose is cumin

Whoever arrives returns not, who knows why is this? 


\section{REFERENCES}

Bayur, Yusuf Hikmet (1983), Türk Inkılabı Taribi [The History of Turkish Revolution], vol. II/1, (Ankara: Türk Tarih Kurumu Yayınları).

Ehiloğlu, Zeki (2001), Yemen'de Türkler (Taribimizin İbret Levbası) [Turks in Yemen (A Lesson from Our History)] (Istanbul: Kitabevi Yayınlar1).

Gn.Kur. (1978), Birinci Dünya Harbinde Türk Harbi, VI. Cilt: Hicaz, Asir, Yemen Cepheleri ve Libya Harekatı [The Turkish War in the World War I, vol. VI: Hijāz, 'Asīr, and Yemen Fronts and Libya Operation] (Ankara: Askeri Tarih ve Stratejik Etüd Başkanlığı (ATASE) Yayınları).

Hourani, Albert H. (1991), A History of the Arab Peoples (Cambridge, Mass.: Belknap Press).

Karal, Enver Z. (1983), Osmanl Taribi [Ottoman History], vol. VI and vol. VIII, (Ankara: Türk Tarih Kurumu Yayınları).

Mehmet Tevfik (Biren) (1993), 'Bir Devlet Adammm' Mebmet Tevfik Bey'in (Biren) II. Abdulhamid, Meşrutiyet ve Mütareke Devri Hattralar ['A Statesman' Mebmed Tawfiq Beg (Biren)'s Memories of the Periods of 'Abd al-Hamìd II, Constitutionalism, and Armistice], vol. I, (ed. F. Rezan Hürmen; Istanbul: Arma Yayınlar1).

Seyhun, Mehmet Arif (1997), "Yemen Savaş Anıları [Yemen War Memoirs]," Askeri Tarih Bülteni [Bulletin of Military History] 22/42, 1-51.

Sırma, İhsan S. (1994), Osmanl Devletinin Yıkılışında Yemen İsyanlar [Revolts in Yemen in the Decay of the Ottoman State] (2 ${ }^{\text {nd }}$ ed., Istanbul: Beyan Yayınları).

TC. BCA [Republic of Turkey, the Republican Archives of the Turkish Prime Ministry] - several folders of documents, whose respective numbers are referred to throughout the paper.

Uzunçarş1l1, İsmail H. (1983), Osmanlı Tarihi [Ottoman History], vol. II and vol. III/1, (Ankara: Türk Tarih Kurumu Yayınları). 